\title{
Monoclonal Antibodies Differentiate Neurofilament and Glial Filament Proteins in the Goldfish Visual Pathway: Probes for Monitoring Neurite Outgrowth from Retinal Explants
}

\author{
Paul S. Jones, ${ }^{2}$ Paul Tesser, ${ }^{1}$ Jan Borchert, ${ }^{1}$ and Nisson Schechter ${ }^{1,3}$ \\ Departments of 'Biochemistry, ${ }^{2}$ Pharmacology, ${ }^{3 P}$ sychiatry and Behavioral Science, Health Sciences Center, State \\ University of New York at Stony Brook, Stony Brook, New York 11794
}

The expression of the neurofilament proteins of the goldfish visual pathway reflects the degeneration and regeneration of the optic nerve after nerve crush. To monitor these processes, monoclonal antibodies (mAb) were generated to the intermediate filament proteins of this pathway.

The predominant goldfish visual pathway intermediate filament proteins have a molecular weight of $58 \mathrm{~K}$ and can be separated into 4 isoelectric variants, 2 of which are neuronal $\left(O N_{1}\right.$ and $O N_{2}$ ) and 2 of which are non-neuronal $\left(O N_{3}\right.$ and $\mathrm{ON}_{4}$ ). The specificities of the mAbs were characterized biochemically and histologically. Immunoblot analysis demonstrated that 2 of the antibodies reacted specifically with the neurofilament proteins $\left(O N_{1} / O N_{2}\right)$ and another antibody reacted specifically with the glial filament proteins $\left(\mathrm{ON}_{3} / \mathrm{ON}_{4}\right)$ and with a $48 \mathrm{~K}$ optic nerve protein of non-neuronal origin. Chymotrypsin digestion of the $O N$ proteins and immunoblotting of the resulting fragments showed that the anti-ON $1 / \mathrm{ON}_{2}$ mAbs were directed toward the variable domains of the filament proteins. In contrast, the anti- $\mathrm{ON}_{3} / \mathrm{ON}_{4} \mathrm{mAb}$ was directed toward the $40 \mathrm{~K}$ chymotrypsin-resistant region of the glial filament proteins containing the conserved intermediate filament core.

When sections of optic nerve tissue were incubated with anti-ON $1 / \mathrm{ON}_{2}$ or anti- $\mathrm{ON}_{3} / \mathrm{ON}_{4}$ mAbs, the staining resulted in either axonal or glial patterns, respectively. In retina, after optic nerve crush, anti- $O N_{1} / O N_{2}$ labeled retinal ganglion cells and Müller fibers. In contrast, prior to optic nerve crush, only Müller fibers were labeled. One of the neuronal-directed mAbs was used to decorate growing neurites from retinal explants; anti-ON $1 \mathrm{~N}_{2}$ reactivity appeared in a time-dependent manner that paralleled the expression of $\mathrm{ON}_{1} / \mathrm{ON}_{2}$ in vivo. Thus, the antibodies can differentiate these 2 types of goldfish intermediate filament proteins and can be used to monitor optic nerve regeneration in the goldfish visual pathway both in vivo and in vitro.

The expression of intermediate filament (IF) proteins has been shown to be developmentally regulated in the nervous system. Of particular relevance to this report are the immunohistological

\footnotetext{
Received Mar. 28, 1988; revised July 18, 1988; accepted July 19, 1988.

This research was supported by a grant from the National Eye Institute, EY05212 to N.S. We wish to thank Dorothy Caselles for assistance in the preparation of the manuscript.

Correspondence should be addressed to Nisson Schechter, Department of Psychiatry, State University of New York at Stony Brook, Stony Brook, NY 11794 Copyright (C) 1989 Society for Neuroscience $0270-6474 / 89 / 020454-12 \$ 02.00 / 0$
}

studies examining the expression of various IF proteins in the developing nervous systems of higher vertebrates (Tapscott et al., 1981; Bignami et al., 1982; Cochard and Paulin, 1984). These studies have shown that the IF protein vimentin (which is normally found in tissues of mesenchymal origin and certain other cell types, including mammalian optic nerve astrocytes) is transiently expressed in neurons during neurogenesis, and its expression is switched off at later stages when the conventional neurofilament proteins are expressed. The observed developmental regulation of IF protein expression further supports the hypothesis that the different IF proteins perform individual functions necessary for specific cell types under various conditions (Franke, 1987; Langley and Cohen, 1987).

The goldfish visual pathway, owing to its capacity for continuous growth and development (Johns and Easter, 1977; Meyer, 1978), as well as its ability to regenerate optic axons after nerve injury (Attardi and Sperry, 1963; Sperry, 1963), has been used as a model system to study these processes. Because of its suitability for experimentation, this system has been the subject of extensive biochemical analyses (Heacock and Agranoff, 1976; Schechter et al., 1979; Quitschke et al., 1980; Benowitz and Lewis, 1983; Perry et al., 1985, 1987). We have been particularly interested in the IFs expressed in the goldfish visual pathway because these proteins may have structural characteristics that support the plasticity and regenerative properties associated with this pathway. The neuro- and glial filaments found in this system do not match those found in the nervous system of adult mammals or birds (Quitschke and Schechter, 1984; Quitschke et al., 1985). A neurofilament triplet is observed in the goldfish optic nerve, but the molecular weights of these proteins are significantly lower than their mammalian counterparts. The predominant IF proteins in this system have molecular weights of $58 \mathrm{~K}$, and they can be separated into at least 4 major components by 2-dimensional gel electrophoresis. These proteins have been designated $\mathrm{ON}_{1}-\mathrm{ON}_{4}$ (optic nerve intermediate filament proteins). Biochemical and immunohistological studies have shown that $\mathrm{ON}_{1}$ and $\mathrm{ON}_{2}$ are neurofilament proteins, while $\mathrm{ON}_{3}$ and $\mathrm{ON}_{4}$ arc glial filament protcins (Quitschkc and Schcchtcr, 1984; Jones et al., 1986a). Peptide fragment analysis and immunological studies have determined that $\mathrm{ON}_{1}$ and $\mathrm{ON}_{2}$ are similar to each other but are different from $\mathrm{ON}_{3}$ and $\mathrm{ON}_{4}$, which are also similar to each other (Jones et al., 1986a; Quitschke and Schecter, 1986). The levels of expression of $\mathrm{ON}_{1} / \mathrm{ON}_{2}$ are affected by optic nerve injury such that their concentrations in the portion of the nerve distal to the site of injury reflect the state of the nerve, i.e., $\mathrm{ON}_{1} / \mathrm{ON}_{2}$ levels decrease soon after nerve 
crush, are restored during regeneration, and reach normal levels with maturation and restoration of vision (Quitschke and Schechter, 1983a, b). Thus, $\mathrm{ON}_{1}$ and $\mathrm{ON}_{2}$ can be used as molecular markers with which to follow nerve growth and regeneration in the goldfish visual pathway.

Previous histological experiments with polyclonal antibodies did not distinguish between normal and postcrush retinal ganglion cells with respect to $\mathrm{ON}_{1} / \mathrm{ON}_{2}$ expression (Jones and Schechter, 1987). Monoclonal antibodies (mAbs) are more discriminating than polyclonal antibodies with respect to the recognition of specific structural features within proteins and are more quantitative bccausc of their reactivities with singular antigenic sites. Therefore, we have prepared $m A$ bs directed against the ON proteins in an effort to develop sensitive immunological probes for histological and structural analysis and to monitor the expression of these proteins. The specificities of these mAbs were characterized by immunoblotting and immunohistochemistry. We also identified the locations of the epitopes recognized by these mAbs within the structural domains of the IF proteins. These mAbs were then used to study the expression of the goldfish neurofilaments in an in vitro model for goldfish visual pathway nerve regeneration, the retinal explant tissue culture system devised by Agranoff(Landreth and Agranoff, 1976, 1979). We show that the neurites grown in this system contain the goldfish neurofilaments $\mathrm{ON}_{1} / \mathrm{ON}_{2}$, further indicating that the neurites growing in vitro are of neuronal origin. We also determined that their expression in the explants follows a time course similar to that observed during nerve regeneration in vivo (Quitschke and Schechter, 1983b).

\section{Materials and Methods}

Animals. Common goldfish (Carassius auratus, 8-12 cm) were obtained commercially from Mt. Parnell Fisheries (Mercersburg, PA) and maintained in 40 gallon tanks at $18^{\circ} \mathrm{C}$. After anesthetization in $0.05 \%$ tricaine methanesulfonate, retrobulbar crush was performed on the right optic nerve. The left optic nerve was left intact to serve as a control.

Protein preparation. Goldfish were anesthetized by immersion in ice water prior to decapitation and tissue removal. Optic nerve proteins were isolated either in a total protein preparation or a cytoskeletal protein preparation. Total proteins were prepared by homogenizing optic nerves in $0.33 \%$ SDS with a glass and Tefion homogenizer. Insoluble matter was pelleted by centrifugation at $8000 \times g$ for $5 \mathrm{~min}$. Proteins were precipitated by the addition of $5 \mathrm{vol}$ of cold acetone $\left(-20^{\circ} \mathrm{C}\right)$ and stored at that temperature overnight. The precipitated protein was pelleted by centrifugation at $2000 \times \mathrm{g}$ for $5 \mathrm{~min}$, air-dried, and homogenized in $0.5 \mathrm{ml}$ distilled water. Aliquots were removed for protein determination (Lowry et al., 1951), and the remainder was lyophilyzed. The protein was then solubilized in $0.05 \mathrm{M}$ Ches buffer ( $\mathrm{pH} 9.0$ ) containing $2 \%$ SDS, $1 \%$ dithiothreitol, and $5 \%$ glycerol.

Total retinal proteins were prepared as described for the optic nerve, with the addition of a pretreatment of the retinae with $10 \%$ Wydase haluronidase solution (Wyeth) in $10 \mathrm{~mm}$ phosphate buffer, pH 7.4, 0.9\% $\mathrm{NaCl}$ to remove the vitreous humor.

Goldfish optic nerve cytoskeletal proteins were isolated as described for rat spinal cord by Chiu et al. (1981). Optic nerves were homogenized in $1.0 \mathrm{ml}$ of $50 \mathrm{~mm}$ Tris- $\mathrm{HCl}(\mathrm{pH} 6.8), 2$ mм EDTA, 2 mм EGTA, $0.5 \% \mathrm{NP}-40,30 \%$ sucrose, and the homogenates were spun at 10,000 $\times g$ for $15 \mathrm{~min}$. Nonionic detergent-insoluble proteins were resuspended in $1.0 \mathrm{ml}$ of the same buffer without sucrose and spun again, and the final pellet was resuspended in $0.5 \mathrm{ml}$ of $0.33 \%$ SDS. Cytoskeletal proteins were then precipitated and either treated as described above or resuspended in $\mathrm{H}_{2} \mathrm{O}$ for chymotrypsin digestion.

$m A b$ production. Monoclonal antibodies were produced at the tissue culture facility of the Department of Microbiology at SUNY, Stony Brook. Four Balb/c mice were injected intraperitoneally on a weekly basis for 6 weeks with an aqueous suspension of a goldfish cytoskeletal protein preparation. Bleedings were taken periodically to test for antibody production. A final injection was given intravenously $4 \mathrm{~d}$ prior to spleen removal and cell fusion. Spleens were removed and a single-cell suspension was made. Red blood cells were lysed, and the remaining spleen cells were mixed with the nonproducing Balb/c-derived myeloma cell line 8653 in a ratio of 10:1. The cell mixture was suspended in $40 \%$ polyethylene glycol in serum-free RPMI media and immediately centrifuged for $6 \mathrm{~min}$ at $500 \times \mathrm{g}$. The cells werc resuspended in $5 \mathrm{vol}$ of serum-free RPMI and centrifuged at $250 \times \mathrm{g}$ for $6 \mathrm{~min}$. The supernatant was aspirated away, and the pellet was resuspended in rat thymusconditioned cloning media [RPMI plus $20 \%$ fetal calf serum (FCS) and $10 \%$ NCTC 109 medium]. The cell suspension was placed in tissue culture flasks and incubated for $24 \mathrm{hr}$ at $37^{\circ} \mathrm{C}$. Clones were grown in cloning medium with the addition of hypoxanthine $\left(10^{-4} \mathrm{M}\right)$, aminopterin $\left(4 \times 10^{-9} \mathrm{M}\right)$, and thymidine $\left(1.5 \times 10^{-5} \mathrm{M}\right)$.

Hybridomas were tested for specific antibody production with an ELISA assay. A $50 \mu \mathrm{g} / \mathrm{ml}$ suspension of goldfish cytoskeletal proteins in $50 \mathrm{~mm}$ carbonate buffer ( $\mathrm{pH} 9.6$ ), $0.02 \%$ azide was prepared. To each well of a 96-well microtiter plate was added $100 \mu$ lof the protein suspension. This was incubated overnight at room temperature. The plates were then washed with Tween PBS $(0.05 \%$ Tween 20 in $10 \mathrm{~mm}$ phosphate buffer, $0.8 \% \mathrm{NaCl}, 2.6 \mathrm{~mm} \mathrm{KCl}, 0.02 \%$ azide). A 1:10 dilution of the hybridoma supernatants in Tween PBS was added to each well and incubated for $2 \mathrm{hr}$ at room temperature. The wells were then washed with three 5 min changes of Tween PBS, and a 1:5000 dilution of alkaline phosphatase-conjugated rabbit anti-mouse Ig antibody (Accurate Chemical) was added to the wells. This was incubated for $1 \mathrm{hr}$, the plates washed with 'Tween PBS, and the enzyme reaction carried out with 1 $\mathrm{mg} / \mathrm{ml} p$-nitrophenyl phosphate (Sigma 104, Sigma) in diethanolamine buffer ( $10 \%$ diethanolamine, $0.5 \mathrm{mM} \mathrm{MgCl}_{2}, 0.02 \%$ azide, $\mathrm{pH} 9.6$ ). After $1 \mathrm{hr}$ of reaction, the absorbance was read at $405 \mathrm{~nm}$ on an ELISA spectrophotometer (Dynatech).

Positive clones were subcloned twice by limiting dilution to insure the selection of single hybridomas. All 3 anti-ON mAbs belong to the IgM class of antibodies as determined by antibody isotyping with an ELISA assay.

Gel electrophoresis and immunoblotting. Two-dimensional polyacrylamide gel electrophoresis (2-D PAGE) was performed essentially as described by O'Farrell (1975) with some previously described modifications (Quitschke and Schechter, 1984). Capillary tubes $2.5 \mathrm{~mm} \times 9$ $\mathrm{cm}$ were used for the isoelectric focusing (IEF) dimension. The seconddimension slab gels were $0.7 \mathrm{~mm}$ thick and were composed of $9 \%$ acrylamide. Either $50 \mu \mathrm{g}$ of total optic nerve proteins or $100 \mu \mathrm{g}$ of total retinal proteins was loaded per gel.

After separation by 2-D PAGE, proteins were transferred to nitrocellulose (Towbin et al., 1979). Gels were sandwiched against nitrocellulose paper (BA-85, Schleicher and Schuell) and transferred in a buffer containing $2.5 \mathrm{~mm}$ Tris, $20 \mathrm{~mm}$ glycine, $0.01 \% \mathrm{SDS}$, and $20 \%$ methanol at $220 \mathrm{~mA}$ for $1.0 \mathrm{hr}$. Blots were blocked in $3 \%$ BSA, $20 \mathrm{~mm}$ Tris- $\mathrm{HCl}$, $\mathrm{pH} 7.4$, and $150 \mathrm{~mm} \mathrm{NaCl}$ for 3-6 hr. Incubations with primary antibodies were carried out in wash buffer $(25 \mathrm{~mm}$ Tris, pH 7.4, $150 \mathrm{~mm}$ $\mathrm{NaCl}, 5 \mathrm{~mm}$ EDTA, $0.3 \%$ BSA, and $0.1 \%$ Tween-20) overnight. Hybridoma supernatants were diluted 1:10, and the anti-intermediate filament monoclonal (AIF) antibody (Pruss et al., 1981) was diluted $1: 100$. Blots were rinsed in wash buffer and incubated with a 1:500 dilution of HRP-conjugated rabbit anti-mouse Ig (Accurate Chemical). Blots were incubated for at least $2 \mathrm{hr}$ at room temperature and washed as before, with a final rinse in $20 \mathrm{~mm}$ Tris, $\mathrm{pH} 7.4$. Immunoreactivity was visualized by developing in $20 \mathrm{~mm}$ Tris, $\mathrm{pH} 7.4,16 \%$ methanol, $0.05 \%$ 4-chloro-1-napthol (Sigma), and 0.03\% hydrogen peroxide. All manipulations were carried out at room temperature.

Chymotrypsin digestion of $O N$ proteins. Goldfish optic nerve cytoskeletal proteins were digested with chymotrypsin $A_{4}$ for $0,10,60$, and $240 \mathrm{~min}$. For each digestion, $120 \mu \mathrm{g}$ protein was treated with $1.2 \mu \mathrm{g}$ chymotrypsin in $50 \mathrm{~mm}$ Tris- $\mathrm{HCl}, \mathrm{pH} 8.0$, in a $160 \mu \mathrm{l}$ reaction volume. At each time point, $30 \mu \mathrm{g}$ was removed, added to an equal volume of $120 \mathrm{~mm}$ Tris $\mathrm{HCl}, \mathrm{pH} 8.8,2.4 \%$ SDS, $280 \mathrm{~mm} \beta$-mercaptoethanol, and $10 \%$ glycerol, and heated at $100^{\circ} \mathrm{C}$ for $1 \mathrm{~min}$. Digested proteins were separated in 1 dimension through a $10 \%$ acrylamide gel, transferred to nitrocellulose, and probed with primary antibodies as described above. Immunoreactivity was determined using alkaline phosphatase-conjugated rabbit anti-mouse Ig at a 1:1000 dilution with subsequent visualization employing 5-bromo-4-chloro-3-indolylphosphate (BCIP) and nitroblue tetrazolium (NBT) at 165 and $500 \mu \mathrm{g} / \mathrm{ml}$, respectively.

Immunohistofluorescence. Fresh, unfixed optic nerve was embedded in high-viscosity embedding medium (O.C.T., Lab Tek products). To prepare retinas for sectioning, goldfish were dark adapted for $1 \mathrm{hr}$. Whole 
retinas were removed from the eye cup and washed twice with PBS, for a total of $20 \mathrm{~min}$. Unfixed retinas were incubated twice for $15 \mathrm{~min}$ with a 1:1 mixture of O.C.T.:Aquamount (Lerner Laboratories) (Jones et al., $1986 \mathrm{~b})$ and then embedded in the same. Both tissues were embedded by freezing in a bath of 2-methyl butane cooled with liquid nitrogen.

Cryostat sections $(10-12 \mu \mathrm{m})$ were picked up onto gelatin-coated slides. Sections were dried at $40^{\circ} \mathrm{C}$ on a slide warmer for $30 \mathrm{~min}$ followed by fixation in $4^{\circ} \mathrm{C}$ acetone for $10 \mathrm{~min}$. The slides were air-dried for 20 min, followed by rehydration with three $10 \mathrm{~min}$ washes of $0.3 \%$ Triton $\mathrm{X}-100$ in $0.1 \mathrm{M}$ sodium phosphate buffer, $\mathrm{pH} 7.4$ (Triton PB). Blocking of nonspecific binding sites was accomplished by incubating sections with a 1:4 dilution of normal goat serum (NGS) in Triton PB for 20 min. Primary antibodies were diluted with Triton PB. Incubations were carried out overnight at $4^{\circ} \mathrm{C}$ in a humidity chamber. Subsequently, the sections were rinsed with three 15 min washes of Triton PB.

Fluorescent studies were performed with FITC-conjugated anti-mouse Ig (Miles-Yeda). The secondary antibody was diluted 1:1000 in Triton $\mathrm{PB}$ and applied to the sections for $2 \mathrm{hr}$ at room temperature in the dark. The slides were washed with three 10 min washes of Triton PB followed by a rinse with PB without Triton before coverslipping. Glycerin-carbonate buffer (9:1), pH 9.5, containing $2 \%$ azide was used as mounting medium. Sections were visualized using a Leitz photomicroscope equipped with epifluorescent illumination and filters for fluorescence.

Some sections were subjected to a mild protease digestion prior to antibody incubations. Acetone-fixed sections of optic nerve were washed with three 5 min changes of $\mathrm{PB}$ (without Triton), followed by fixation in $2 \%$ paraformaldehyde in $\mathrm{PB}$ for $30 \mathrm{~min}$ at room temperature. Sections

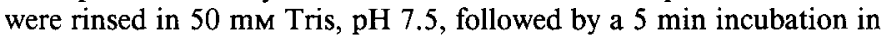
$0.025 \%$ Pronase (Sigma) in $50 \mathrm{~mm}$ Tris, $\mathrm{pH} \mathrm{7.5}$. The enzyme was washed away with three 5 min changes of Triton PB. Sections were then treated as described above.

Control experiments were performed by omitting the primary antibody. No fluorescence was observed on these sections.

Retinal explant tissue culture. The culturing of retinal explants was performed essentially as described by Landreth and Agranoff (1976, 1979) with some modifications described here. Glass coverslips were cleaned with acetone, air-dried, and incubated for $1 \mathrm{hr}$ in $5 \mathrm{mg} / \mathrm{ml}$ polyL-lysine, approximately $52,000 \mathrm{M}$.W., in sterile filtered $0.1 \mathrm{M}$ sodium borate buffer, $\mathrm{pH}$ 8.4. After drying overnight, the coverslips were washed with at least 4 changes of sterile distilled water for a total of $24 \mathrm{hr}$. The coverslips were placed in $35 \mathrm{~mm}$ sterile plastic petri dishes (Nunc) and adhered in place with a small amount of vacuum grease.

Goldfish that had undergone nerve crush 7-14 d earlier were darkadapted for at least $1 \mathrm{hr}$. Under a red safe light the fish were decapitated, and the experimental eyes were removed and sterilized by immersion in $70 \%$ ethanol for $30 \mathrm{sec}$. The front of each eye was excised away and the lens was removed. The optic disc was cut out of the center of the retina with a sterilized Pasteur pipette. The retina was then taken out of the eyecup, and the pigment epithelium was stripped from the back of the retina. Retinae were washed in a series of sterile PBS $(2.6 \mathrm{~mm}$ $\mathrm{KCl}, 1.5 \mathrm{~mm} \mathrm{KH}{ }_{2} \mathrm{PO}_{4}, 137 \mathrm{~mm} \mathrm{NaCl}, 6.5 \mathrm{~mm} \mathrm{Na} \mathrm{HPO}_{4}, 5 \mathrm{~mm} \mathrm{MgCl}$, $9 \mathrm{mM} \mathrm{CaCl}_{2}$ ) to remove vitreous humor. Retinae were chopped into $500 \mu \mathrm{m}$ squares with a McIlwain tissue chopper. The pieces were washed 3 times with PBS and allowed to settle. A final rinse was done with culture media (Gibco L-15, supplemented with $20 \mathrm{mM}$ HEPES, pH 7.2, $0.1 \mathrm{mg} / \mathrm{ml}$ gentamycin sulfate, $0.1 \mathrm{~mm} 5$-fluoro-2'-deoxyuridine, 0.2 mM uridine, 1\% FCS).

The coverslips were wetted with culture media, drained, and retina pieces were placed onto them. The explants were allowed to sit for approximately $30 \mathrm{~min}$ before a small amount of culture media was added. Additional media was given the following day. Explants were grown in humidity chambers at ambient temperatures.

At specified times after culture, the coverslips were removed from the petri dishes, drained of media, immersed in cold $\left(4^{\circ} \mathrm{C}\right)$ acetone for $10 \mathrm{~min}$, and air-dried. Preparation for immunolocalization studies followed the procedure described for tissue sections, with the exception that the buffer used for washes and antibody dilution was $0.1 \mathrm{M}$ phosphate buffer, $\mathrm{pH} 7.4$, without the detergent.

\section{Results}

\section{Specificities of anti-ON mAbs}

The specificities of the mAbs raised against the goldfish cytoskeletal proteins were determined by immunoblotting total optic nerve proteins separated by 2-D PAGE. The distribution of the
ON proteins on 2-D PAGE has been reported earlier (Quitschke and Schechter, 1983a, b). Immunoblots were first probed with the $\mathrm{mAbs}$ directed against the ON proteins. These same immunoblots were then reprobed with the AIF antibody (Pruss et al., 1981), which has been shown to react with all of the ON proteins (Quitschke et al., 1985). This reprobing established the proteins for which the anti-ON mAbs are specific. Three mAbs were selected and were designated as mAb 396 (Fig. 1A), mAb 187 (Fig. 1C), and mAb 84 (Fig. 1E). The corresponding reprobed blots are also shown (Fig. $1, B, D$, and $F$, respectively) Both $\mathrm{mAb} 396$ and $\mathrm{mAb} 187$ react with $\mathrm{ON}_{1}$ and $\mathrm{On}_{2}$, and with a protein located between $\mathrm{ON}_{3}$ and $\mathrm{ON}_{4}$, which has previously been shown to act similarly to the neurofilaments $\mathrm{ON}_{1}$ and $\mathrm{ON}_{2}$ after nerve crush (Quitschke and Schechter, 1984). Very low levels of cross-reactivity with $\mathrm{ON}_{3}$ and $\mathrm{ON}_{4}$ were observed with these antibodies. Monoclonal antibody 187 was also shown to react very weakly with proteins at $48 \mathrm{~K}$. Monoclonal antibody 84 reacts with the non-neuronal $\mathrm{ON}$ proteins $\left(\mathrm{ON}_{3}\right.$ and $\left.\mathrm{ON}_{4}\right)$, as well as with the proteins at $48 \mathrm{~K}$. These $48 \mathrm{~K}$ proteins have been determined to be of non-neuronal origin, and they share some, but not all, characteristics with IF proteins (Quitschke et al., 1985).

To determine the locations of the antigenic sites recognized by these antibodics with respect to the structural domains of the IF proteins, the proteins in a goldfish optic nerve cytoskeletal preparation were digested with chymotrypsin, and the resulting fragments were separated by SDS-PAGE, blotted, and probed with the mAbs. Figure $2 A$ is a Coomassie Blue-stained gel of the proteins at various times of digestion (undigested, 10,60, $240 \mathrm{~min})$. At the longest digestion time $(240 \mathrm{~min})$, the only bands stained with Coomassie Blue are at approximately $40 \mathrm{~K}$ and represent the chymotrypsin-resistant region containing the conserved alpha-helical-rich core common to IF proteins. The presence of several chymotrypsin-resistant bands is consistent with the fact that several proteins are contributing these fragments. An immunoblot probed with the AIF antibody is shown in Figure $2 B$, demonstrating that the $40 \mathrm{~K}$ chymotrypsin-resistant region of the ON proteins contains the epitope recognized by this antibody. At the longest digestion time, only the $40 \mathrm{~K}$ fragments are immunolabeled (indicated by brackets). The immunoreactivities of $\mathrm{mAb} 396, \mathrm{mAb} 187$, and $\mathrm{mAb} 84$ toward these digests are shown in Figure 2, $C, D$, and $E$, respectively. After 60 min of digestion, both anti-neurofilament antibodies (mAb 396 and $\mathrm{mAb}$ 187) react with a digest product that is larger than the $40 \mathrm{~K}$ fragment (indicated by arrows). These antibodies display no reactivity with any fragment at the longest digestion time when only the $40 \mathrm{~K}$ fragments remain. This suggests that these antibodies recognize an epitope that is located in the chymotrypsin-sensitive region outside the core. Monoclonal antibody 84 reacts with an epitope in the $40 \mathrm{~K}$ chymotrypsin-resistant region, as shown in Figure $2 E$. No reactivity with either larger or smaller fragments after extended digestion is observed with this antibody.

\section{Histological characterization of anti-ON $m A b$ immunoreactivity on optic nerve sections}

The $\mathrm{mAbs}$ were used to differentiate the patterns of reactivity for the IF proteins of neuronal $\left(\mathrm{ON}_{1} / \mathrm{ON}_{2}\right)$ and non-neuronal $\left(\mathrm{ON}_{3} / \mathrm{ON}_{4}\right)$ origin on histological sections of goldfish optic nerve. Both anti-neurofilament mAbs gave identical reaction patterns. On cross sections (Fig. $3 A$ ), a punctate pattern was observed, whereas on longitudinal sections (Fig. $3 B$ ), parallel fibers run- 

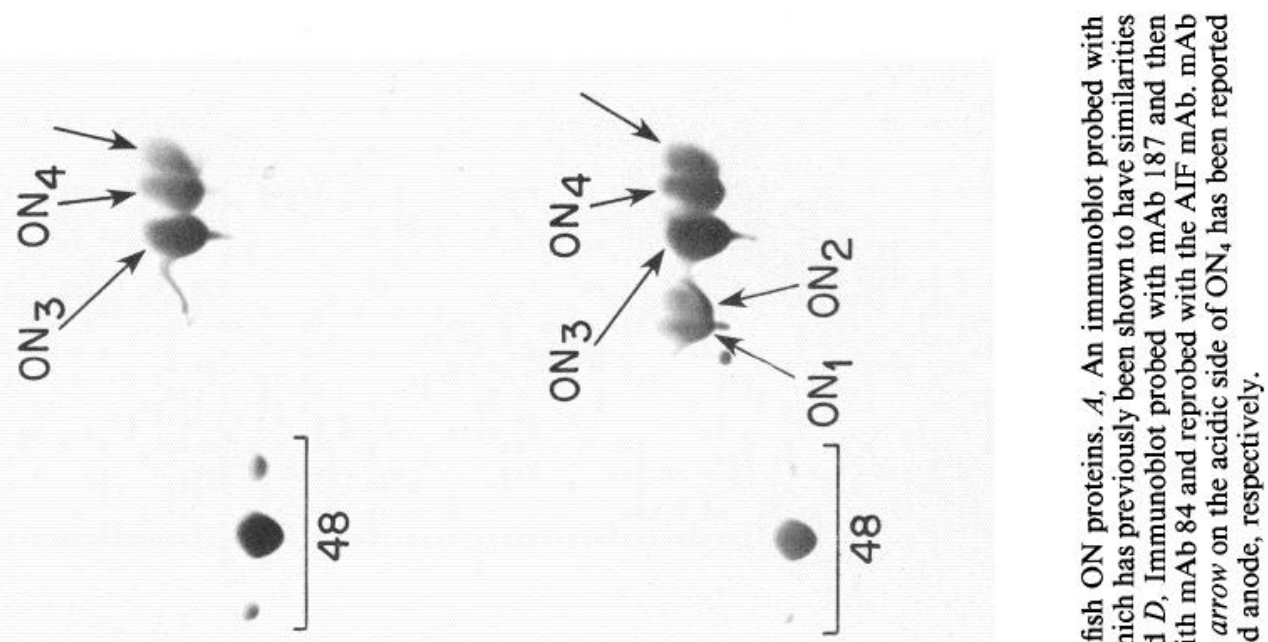

U

u
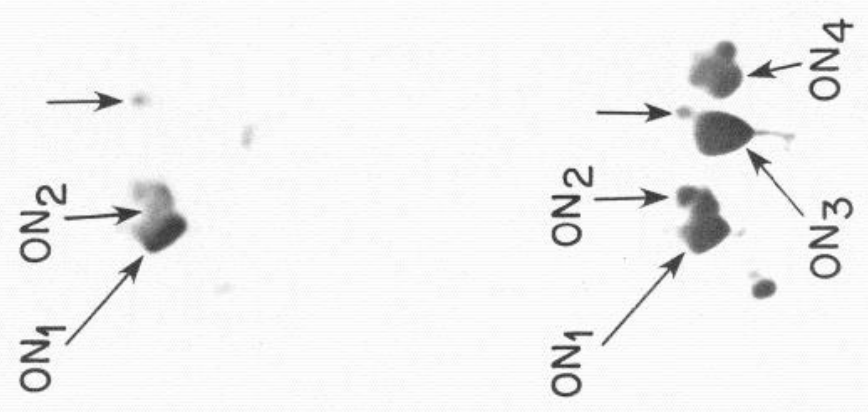

$\circlearrowleft$
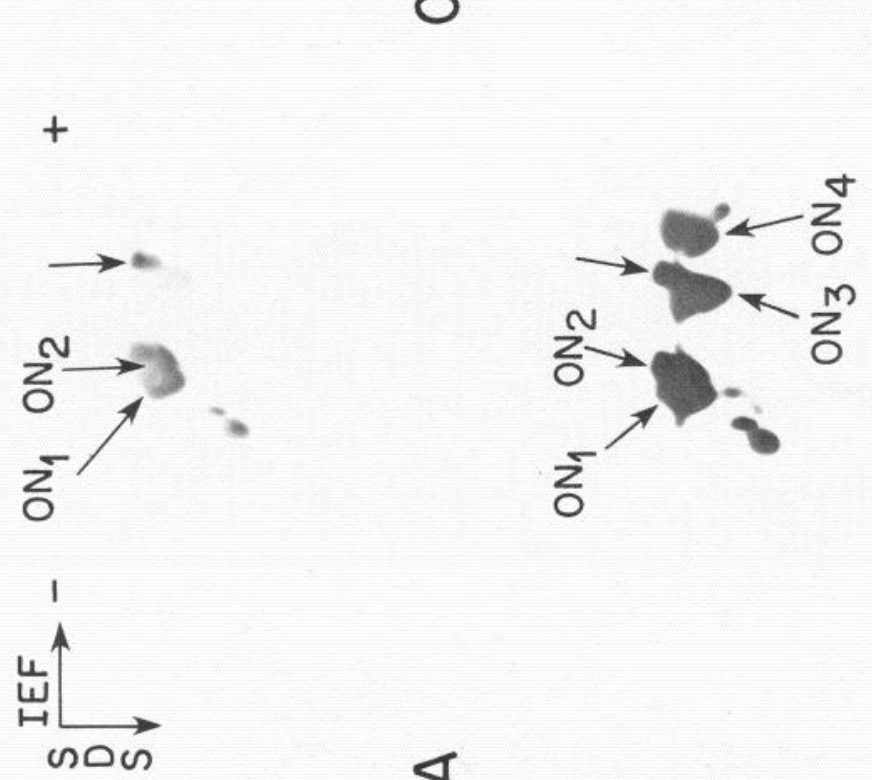

$0 \quad$ it

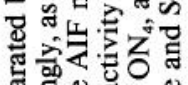

觔范

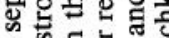

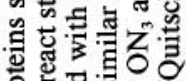

o

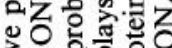

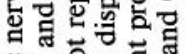

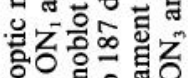

뜰

웡. ㅈ.

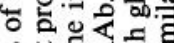

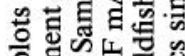




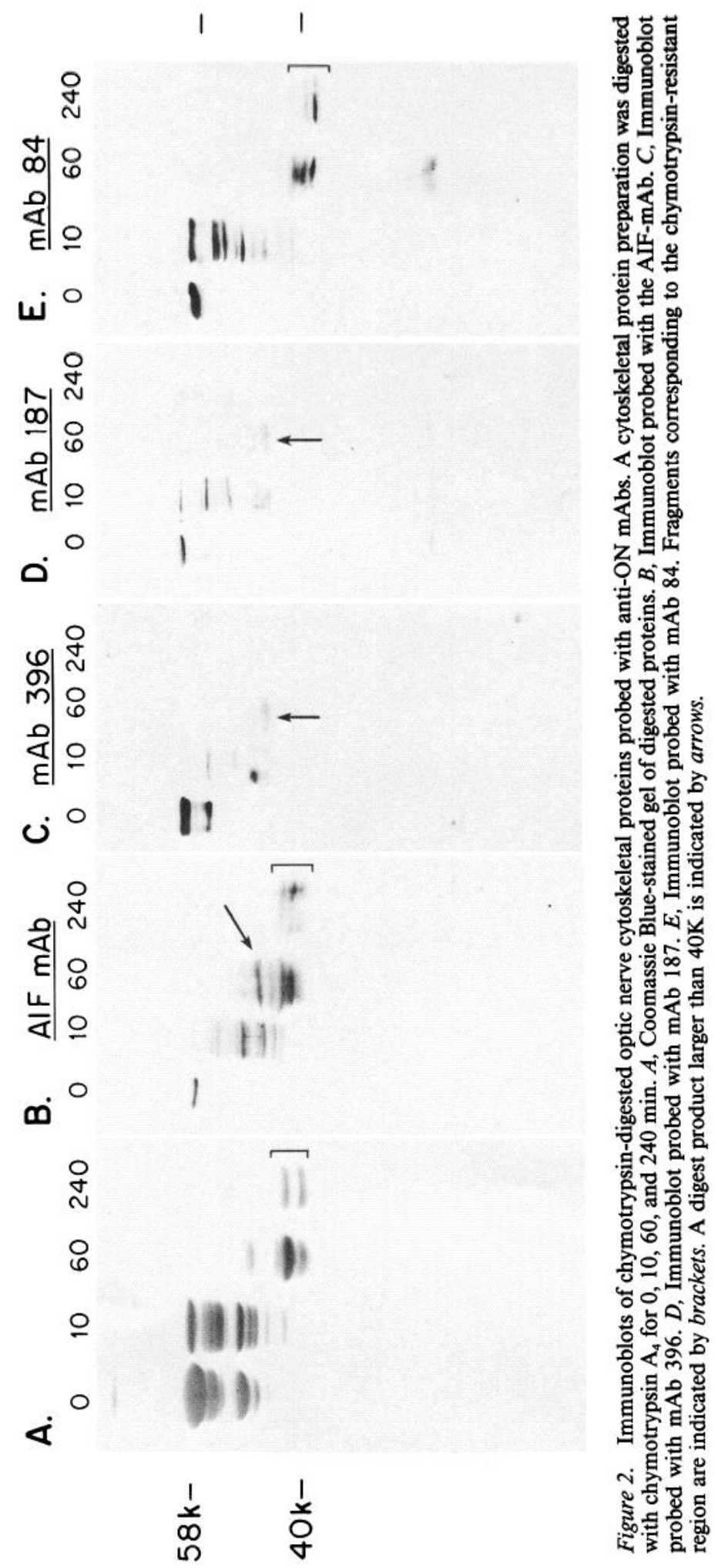



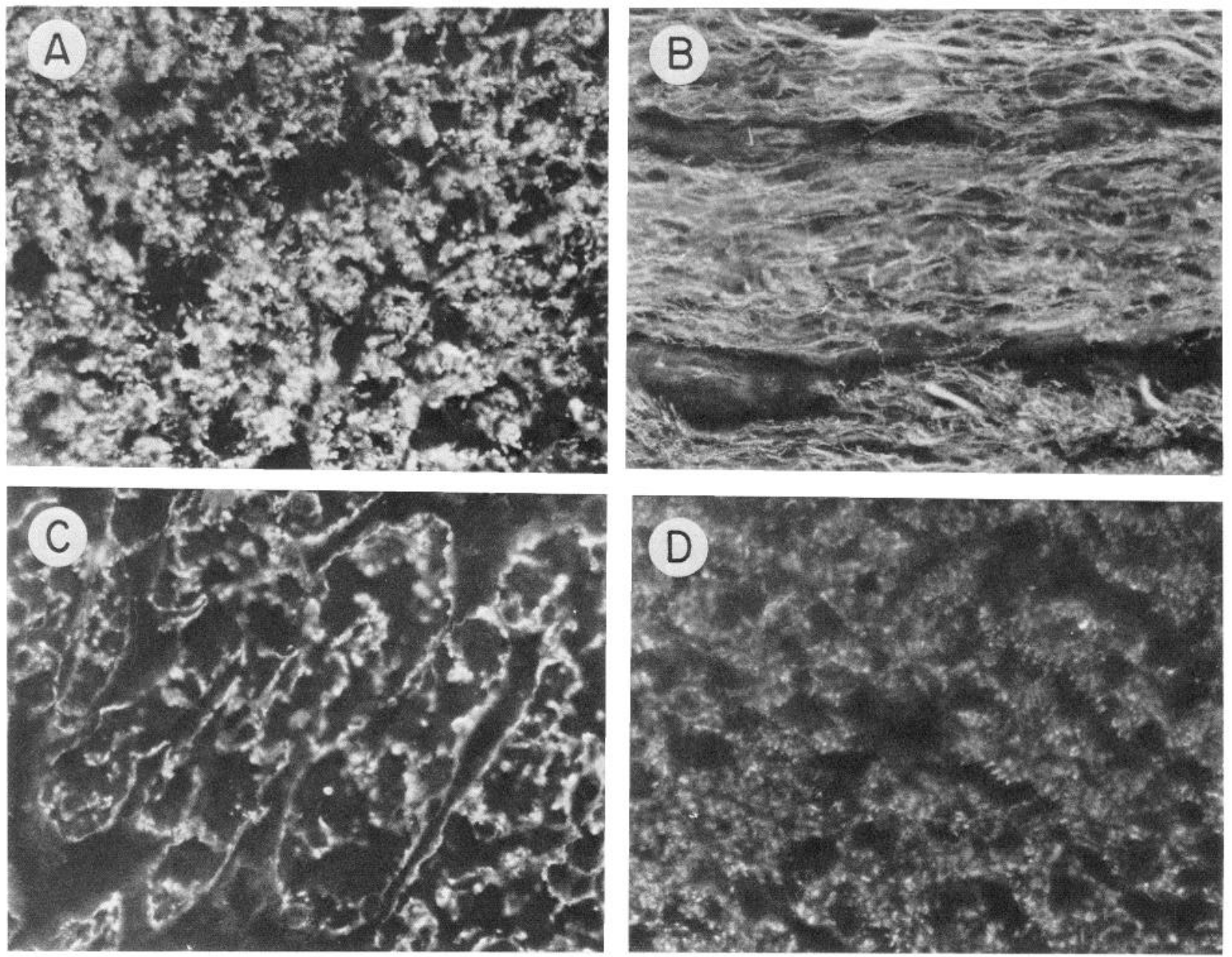

Figure 3. Immunohistological characterization of anti-ON mAb reactivities on cryosections of fresh-frozen goldfish optic nerve. $A$ and $B$, Cross section and longitudinal section, respectively, of optic nerve reacted with $\mathrm{mAb} 396$. $C$, Protease-treated cross section of optic nerve probed with $\mathrm{mAb} 84$. D. Protease-treated cross section of optic nerve probed with $\mathrm{mAb} 187$. Antibody reactivity in all sections was visualized using indirect immunofluorescence. Magnification: $A, C$, and $D, \times 460 ; B, \times 280$.

ning in the direction of the nerve were labeled. These patterns of reactivity were confined to the fascicles and are consistent with intraaxonal staining. These results are identical to those obtained with polyclonal antibodies specific for $\mathrm{ON}_{1}$ and $\mathrm{ON}_{2}$ (Jones et al., 1986a). Monoclonal antibody 84 did not react with sections of optic nerve treated under the same conditions in which the anti-ON $\mathrm{N}_{1} / \mathrm{ON}_{2}$ mAbs clearly labeled axons. Only if the tissue sections were first subjected to a mild protease digestion was reactivity observed with this antibody (Fig. $3 C$ ). The resulting staining pattern is similar to the pattern observed when normal optic nerve cross sections are probed with polyclonal antibodies specific for $\mathrm{ON}_{3}$ and $\mathrm{ON}_{4}$, although some amount of structure and clarity is lost with the tissue digestion. The observed pattern is consistent with a glial staining pattern. That the staining pattern resulting from this treatment is specific and not due to antibody trapping is demonstrated by probing another protease-treated optic nerve cross section with mAb 187 (Fig. $3 D$ ). Incubation with this antibody results in an axonal staining pattern in the protease-treated tissue similar to that obtained with nondigested tissue, and this pattern is distinctly different from that observed with $\mathrm{mAb} 84$.

\section{Characterization of anti-ON $\mathrm{mAb}$ reactivity in goldfish retina}

The specificities of the anti-ON mAbs for proteins found in the goldfish retina were determined by immunoblotting and immunohistofluorescence. Total retinal proteins were separated by 2-D PAGE and transferred to nitrocellulose filters. The locations of the ON proteins and other putative IF proteins in the goldfish retina have been determined previously (Jones and Schechter, 1987). Both anti-neurofilament antibodies $\mathrm{mAb} 396$ and $\mathrm{mAb}$ 187 gave similar results on immunoblots (Fig. 4, $A, B$, respectively). The difference in the levels of reactivity between $\mathrm{mAb}$ 396 and mAb 187 seen on these blots is most likely due to the lower titer of $\mathrm{mAb} 187$. Both of these mAbs reacted with $\mathrm{ON}_{1}$ and $\mathrm{ON}_{2}$, as well as with the putative IF proteins at $60 \mathrm{~K}$, and with a protein at $58 \mathrm{~K}$ on the acidic side of $\mathrm{ON}_{2}$ that is thought to be similar to $\mathrm{ON}_{3}$. These proteins are also the major proteins labeled with the AIF antibody on retinal immunoblots (Jones and Schechter, 1987). Furthermore, all of these proteins, with the exception of the $\mathrm{ON}_{3}$-like protein, react with an anti-mammalian glial fibrillary acidic protein (GFAP) polyclonal antiserum (Jones and Schechter, 1987). On a retinal immunoblot, 


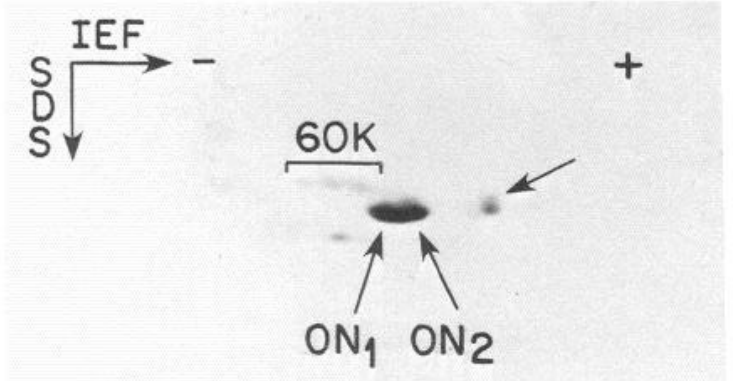

A
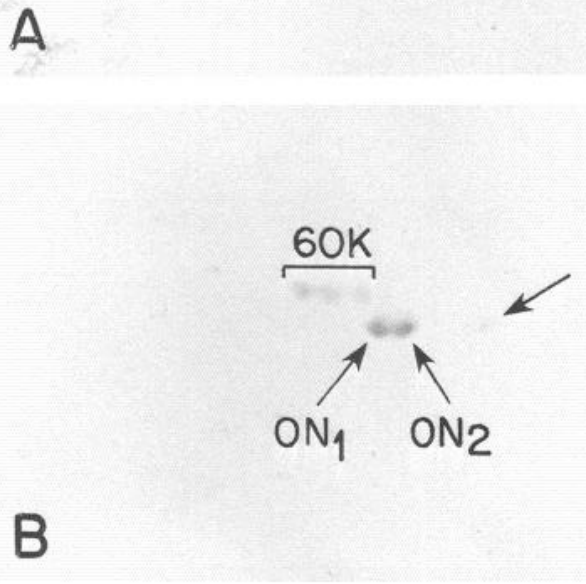

B

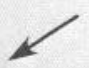

Figure 4. Immunoblots of total retinal proteins probed with the mAbs. $A$, Immunoblot probed with mAb 396. Proteins at $60 \mathrm{~K}$ are indicated with a bracket. $B$, Immunoblot probed with $\mathrm{mAb} 187$. $C$, Immunoblot probed with $\mathrm{mAb} 84$. Abbreviations are denoted in the legend for Figure 1. An $\mathrm{ON}_{3}$-like protein on the acidic side of $\mathrm{ON}_{2}$ is indicated with an arrow.

mAb 84 reacted with the $\mathrm{ON}_{3}$-like $58 \mathrm{~K}$ protein on the acidic side of $\mathrm{ON}_{2}$ (Fig. 4C).

The anti-neurofilament antibodies were used on fresh-frozen sections of normal and postnerve crush goldfish retina. Similar results were obtained with both $\mathrm{mAb} 396$ and $\mathrm{mAb}$ 187. In the normal retina, mAb 396 predominantly labels the Müller fibers (Fig. 5A). Little or no staining of retinal ganglion cells is observed in normal tissue. This staining pattern is similar to that observed in goldfish retina probed with anti-mammalian GFAP antibodies (Bignami, 1984; Jones and Schechter, 1987). In contrast, at $20 \mathrm{~d}$ after optic nerve crush, when $\mathrm{ON}_{1}$ and $\mathrm{ON}_{2}$ synthesis is near its peak (Quitschke and Schechter, 1983b; Tesser et al., 1986), a different staining pattern is observed (Fig. $5 B$ ). In addition to stained Müller fibers, the retinal ganglion cells are also clearly labeled at this time point. Furthermore, some staining of the inner nuclear layer can be seen in both normal and post- crush tissue. This staining could be either Müller cell somata or horizontal cells.

\section{Decoration of neurites from retinal explants with anti-goldfish neurofilament antibodies}

We carried out experiments to determine whether $\mathrm{ON}_{1}$ and $\mathrm{ON}_{2}$ are expressed in neurites in the goldfish retinal explant tissue culture system as developed by Landreth and Agranoff (1976, 1979). Explants were grown on poly-L-lysine-coated coverslips in petri dishes. At various times, the coverslips were removed from the dishes, fixed in cold acetone, and prepared for im munofluorescence. Figure $6 \mathrm{~A}$ shows a phase-contrast photomicrograph of an explant after $4 \mathrm{~d}$ of culture. When this explant is treated with $\mathrm{mAb} 396$, no reactivity is associated with the neurites (Fig. $6 B$ ). At day 6 after culture (Fig. 6, $C, D$ ), a neurite at the top of the photograph is labeled by mAb 396, whereas another neurite, seen at the bottom of the phase-contrast photograph, is not detected with immunofluorescence. This represents the time point at which $\mathrm{ON}_{1} / \mathrm{ON}_{2}$ expression is initially observed. At later time points (Fig. 6, E, F), all neurites react with the anti-neurofilament monoclonal antibody. The cell in Figure 6, indicated by an arrow, reacts with mAb 396 and may be a migrating ganglion cell or a Müller cell. Monoclonal antibody 84 was never observed to react with these neurites.

\section{Discussion}

We have prepared and characterized mAbs to the predominant $58 \mathrm{~K} \mathrm{IF}$ proteins of the goldfish visual pathway. These antibodies are specific in their ability to differentiate between the neurofilament $\left(\mathrm{ON}_{1} / \mathrm{ON}_{2}\right)$ and the glial filament $\left(\mathrm{ON}_{3} / \mathrm{ON}_{4}\right)$ proteins. The molecular and histological specificities of the antibodies discussed here are summarized in Tables 1 and 2.

\section{Biochemical characterization of $m A b s$}

Two antibodies (mAb 396 and $\mathrm{mAb} 187$ ) were specific for the neurofilament proteins $\mathrm{ON}_{1}$ and $\mathrm{ON}_{2}$, and the other antibody $(\mathrm{mAb} 84)$ was specific for the glial filament proteins $\mathrm{ON}_{3}$ and $\mathrm{ON}_{4}$ and non-neuronal proteins at $48 \mathrm{~K}$. No antibody was found that reacted with only a single $\mathrm{ON}$ protein. These data indicate that the 2 groups of antigens contain epitopes distinct from each other, and the epitopes responsible for recognition by our mAbs within each group are identical or nearly identical. This is in agreement with previous peptide fragment analysis, which showed that even though all of the ON proteins contain some common fragments, $\mathrm{ON}_{1}$ and $\mathrm{ON}_{2}$, which are very similar to each other, are different from $\mathrm{ON}_{3}$ and $\mathrm{ON}_{4}$, which are also very similar to each other (Quitschke and Schechter, 1986).

Previous studies have shown that proteins $\mathrm{ON}_{2}$ and $\mathrm{ON}_{4}$ are phosphorylated both in vivo and in vitro (Quitschke and Schechter, 1984; Larrivee and Grafstein, 1987). These variable phosphorylation states of the goldfish neurofilament and glial filament proteins may account for the different IEF points within each group. However, antibodies were not found to react solely with the phosphorylated forms of the goldfish IFs.

A surprising result was that $\mathrm{mAb} 84$, which reacts with $\mathrm{ON}_{3}$ and $\mathrm{ON}_{4}$, also reacts with proteins at $48 \mathrm{~K}$. These $48 \mathrm{~K}$ nonneuronal optic nerve proteins share qualities with IF proteins in that they are non-ionic-detergent insoluble (Quitschke and Schechter, 1984), and they possess a $40 \mathrm{~K}$ chymotrypsin-resistant region (Quitschke and Schechter, 1986). They do not react with the AIF antibody, however. Interestingly, the major $48 \mathrm{~K}$ proteins react very strongly with $\mathrm{a} \mathrm{mAb}$ isolated and described 

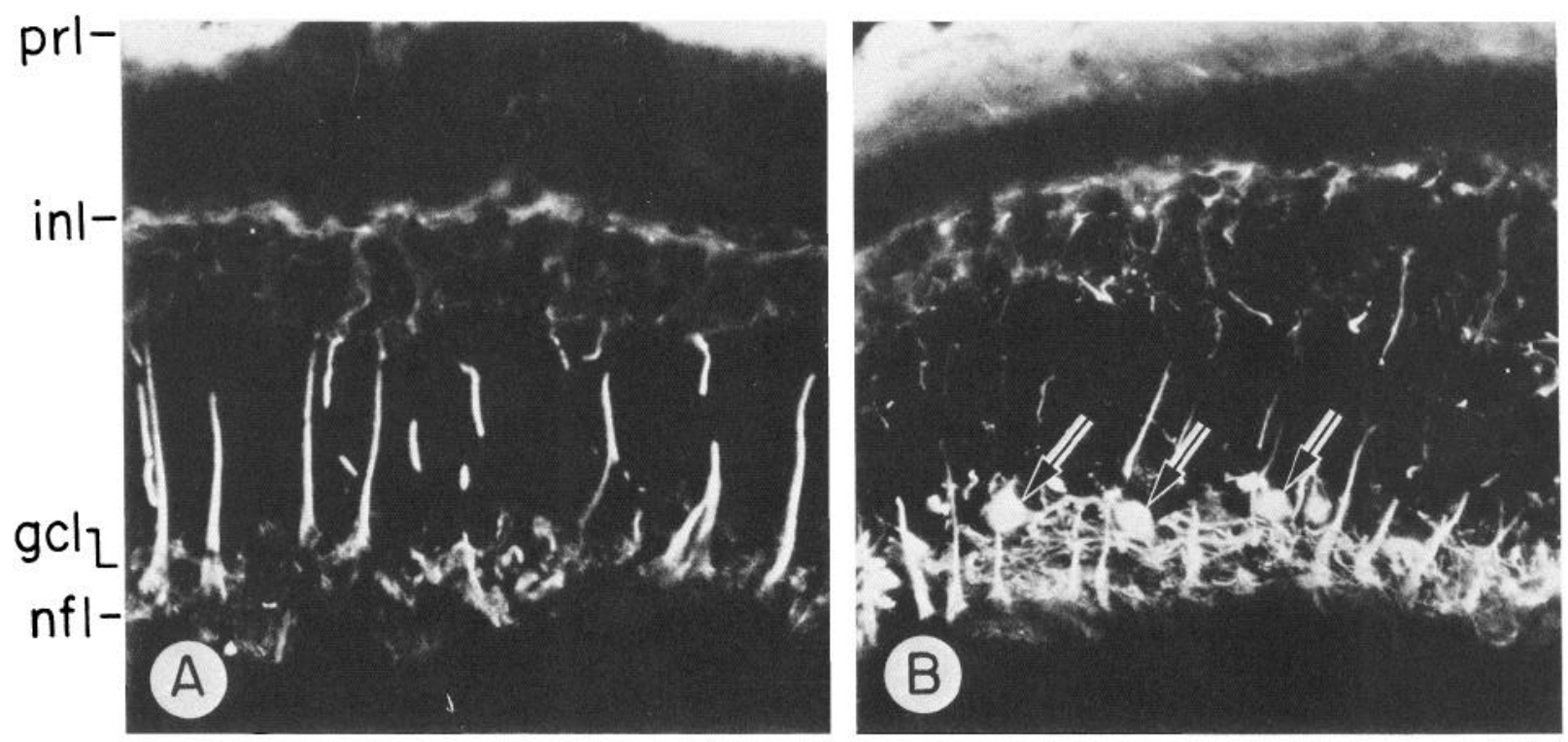

Figure 5. Reactivity of mAb 396 on normal and postcrush (induced) goldfish retina. $A$, Normal retina probed with mAb $396 . B$, induced (26 d postcrush) retina probed with $\mathrm{mAb} 396$. Arrows indicate retinal ganglion cells. Antibody reactivity was visualized using indirect immunofluorescence. The bright region bordering the outer surface of the retina (top of photomicrograph) is due to the autofluorescence of the photoreceptors. prl, photoreceptor layer; inl, inner nuclear layer; $g c l$, ganglion cell layer; $n f l$, nerve fiber layer. $\times 320$.

by Walter and Biessmann (1984) directed against a drosophila vimentin-like protein (unpublished results) but do not crossreact with antibodies raised against mammalian vimentin (Quitschke et al., 1985). These data, taken together, suggest that the $48 \mathrm{~K}$ proteins may be IF proteins in which the epitope for the AIF antibody within the conserved IF core is altered.

The structural organization of the goldfish optic nerve intermediate filament proteins is similar to the more extensively studied mammalian IFs. As with the mammalian neurofilaments, chymotrypsin digestion of the ON proteins results in a time-dependent production of the major resistant $40 \mathrm{~K}$ fragments that contain the conserved IF core (Geisler et al., 1982, 1983). Immunoblot analysis of the ON protein fragments determined that $\mathrm{mAb} 396$ and $\mathrm{mAb}$ 187, which are specific for the neurofilament proteins $\left(\mathrm{ON}_{1} / \mathrm{ON}_{2}\right)$, react with fragments that are larger than the $40 \mathrm{~K}$ resistant region. No reactivity is ob- served at the longest digestion time when only the $40 \mathrm{~K}$ fragments remain. These data demonstrate that these antibodies react with the variable domains, which impart singularity to particular IF proteins. Monoclonal antibody $\mathrm{mAb} 84$, which is specific for the glial-filament proteins $\left(\mathrm{ON}_{3} / \mathrm{ON}_{4}\right)$, reacts at the longest time point only with $40 \mathrm{~K}$ fragments. This antibody does not cross-react with the goldfish neurofilament proteins which also contain a $40 \mathrm{~K}$ chymotrypsin-resistant fragment. This suggests that the $40 \mathrm{~K}$ core produced after chymotrypsin digestion of the $\mathrm{ON}_{3} / \mathrm{ON}_{4}$ proteins may contain a stretch of the variable region adjacent to the core region. Alternatively, the antibody may be reacting with an $\mathrm{ON}_{3} / \mathrm{ON}_{4}$-specific amino acid sequence contained within the conserved core. An examination of IF protein core structure reveals that most of the core contains alpha-helical-rich domains with highly conserved amino acid sequences. However, linker regions between these domains are

Table 1. Immunochemical specificity

\begin{tabular}{|c|c|c|c|}
\hline Antibody & Optic nerve & Retina & Domain \\
\hline AIF & $\mathrm{ON}_{1}-\mathrm{ON}_{4}$ & $\begin{array}{c}\mathrm{ON}_{1}, \mathrm{ON}_{2}, \mathrm{ON}_{3} \text {-like } \\
\text { protein and } 60 \mathrm{~K}\end{array}$ & Carboxyl region of $40 \mathrm{~K}$ core \\
\hline $\begin{array}{l}\text { Polyclonal } \\
\mathrm{ON}_{1} / \mathrm{ON}_{2}\end{array}$ & $\mathrm{ON}_{1}$ and $\mathrm{ON}_{2}^{a}$ & $\mathrm{ON}_{1}$ and $\mathrm{ON}_{2}^{b}$ & Variable region \\
\hline $\begin{array}{l}\text { Polyclonal } \\
\mathrm{ON}_{3} / \mathrm{ON}_{4}\end{array}$ & $\mathrm{ON}_{3}$ and $\mathrm{ON}_{4}{ }^{a}$ & $\mathrm{ON}_{3}$-like protein ${ }^{b}$ & N.D. \\
\hline mAb 396 & $\mathrm{ON}_{1}$ and $\mathrm{ON}_{2}$ & $\begin{array}{l}\mathrm{ON}_{1}, \mathrm{ON}_{2}, \mathrm{ON}_{3} \text {-like } \\
\text { protein and } 60 \mathrm{~K}\end{array}$ & Variable region \\
\hline $\mathrm{mAb} 187$ & $\mathrm{ON}_{1}$ and $\mathrm{ON}_{2}$ & $\begin{array}{l}\mathrm{ON}_{1}, \mathrm{ON}_{2}, \mathrm{ON}_{3} \text {-like } \\
\text { protein and } 60 \mathrm{~K}\end{array}$ & Variable region \\
\hline $\mathrm{mAb} 84$ & $\mathrm{ON}_{3}, \mathrm{ON}_{4}$, and $48 \mathrm{~K}$ & $\mathrm{ON}_{3}$-like protein & $\begin{array}{l}40 \mathrm{~K} \text { chymotrypsin-resistant region } \\
\text { containing the conserved core }\end{array}$ \\
\hline
\end{tabular}

\footnotetext{
${ }^{a}$ Jones et al., 1986.

${ }^{b}$ Jones and Schechter, 1987.

' Pruss et al., 1981.
} 
Table 2. Histological specificity

\begin{tabular}{|c|c|c|c|}
\hline \multirow[b]{2}{*}{ Antibody } & \multirow[b]{2}{*}{ Optic nerve } & \multicolumn{2}{|l|}{ Retina } \\
\hline & & Precrush & Postcrush \\
\hline $\begin{array}{l}\text { Polyclonal } \\
\mathrm{ON}_{1} / \mathrm{ON}_{2}\end{array}$ & Axonal $^{a}$ & $\mathrm{RGC}^{\prime}$ & $\mathrm{RGC}^{b}$ \\
\hline $\begin{array}{l}\text { Polyclonal } \\
\mathrm{ON}_{3} / \mathrm{ON}_{4}\end{array}$ & Glial cells ${ }^{a}$ & Horizontal cells ${ }^{b}$ & Horizontal cells ${ }^{b}$ \\
\hline mAb 396 & Axonal & $\begin{array}{l}\text { Müller fibers, inner } \\
\text { nuclear layer }\end{array}$ & $\begin{array}{l}\text { Müller fibers, inner } \\
\text { nuclear layer, RGC }\end{array}$ \\
\hline $\mathrm{mAb} 187$ & Axonal & $\begin{array}{l}\text { Müller fibers, inner } \\
\text { nuclear layer }\end{array}$ & $\begin{array}{l}\text { Müller fibers, inner } \\
\text { nuclear layer, } R G C\end{array}$ \\
\hline $\mathrm{mAb} 84$ & Glial $^{d}$ & N.D. & N.D. \\
\hline Anti-GFA & No rcactivityr & Müller fibers ${ }^{h}$ & Müller fibers ${ }^{b}$ \\
\hline
\end{tabular}

much less conserved and, although accounting for a small fraction of the total core region, would allow for mAbs reacting within the core to discriminate between different $\mathrm{IF}$ proteins (Steinert and Parry, 1985).

\section{Histological characterization of $m A b$ s on optic nerve}

The histological specificity of the antibodies toward the goldfish ON proteins can be interpreted in terms of the structure of the proteins and their disposition within tissue sections. The mAbs directed against $\mathrm{ON}_{1} / \mathrm{ON}_{2}$ reacted with axons in sections of optic nerve. Monoclonal antibody 84 , which is specific for the $40 \mathrm{~K}$ chymotrypsin-resistant region of the goldfish glial filament proteins, will not react with histological sections of goldfish optic nerve under normal conditions. The AIF antibody, which reacts with the carboxyl region of the conserved core contained within the $40 \mathrm{~K}$ region, also does not react well with tissue sections ( $R$. Pruss, personal communication). The coiled-coil arrangement with the IF core may prevent antibodies from binding to their antigenic sites in vivo; however, under denaturing conditions, such as electrophoresis through SDS gels, these sites can become available for binding. Prior to incubations with $\mathrm{m} \Lambda \mathrm{b} 84$, optic nerve sections were subjected to a mild protease treatment to expose epitopes within the core region. The resulting histological pattern is reminiscent of astrocytic labeling. When Pronasetreated sections were incubated with a polyclonal antibody directed against $\mathrm{ON}_{3} / \mathrm{ON}_{4}$ (which does not require prior digestion of the tissue to react), the pattern was similar to that obtained with $\mathrm{mAb} 84$, demonstrating that the antigenic site is still present (data not shown). When Pronase-treated sections were incubated with $\mathrm{mAb} 187$, the resulting pattern was consistent with axonal staining, demonstrating that the pattern obtained from $\mathrm{mAb} 84$ incubations is not a result of nonspecific trapping of antibody by digested tissue.

\section{IF protein expression in the goldfish retina}

Sections of normal and postoptic nerve crush goldfish retina were probed with $\mathrm{mAbs}$ directed against $\mathrm{ON}_{1} / \mathrm{ON}_{2}$ to determine if the staining pattern in retinal ganglion cells would reflect the expression of these proteins during regeneration. In normal retina, both mAb 396 and 187 labeled only Müller fibers. In contrast, in postcrush retina, retinal ganglion cells were clearly la- beled, in addition to the Müller fibers. Earlier histological experiments with polyclonal antibodies showed no difference in staining between experimental and control sections, despite previous biochemical results demonstrating an increase in $\mathrm{ON}_{1} /$ $\mathrm{ON}_{2}$ synthesis after nerve crush. The most likely explanation for the observed differences between the 2 antibody preparations is that the polyclonal antibody cannot distinguish between steadystate synthesis and induced synthesis because a multiplicity of epitopes is recognized, and this results in substantial reactivity in both states. Only a single epitope is recognized by the mAb, and it is only in the induced state where sufficient binding reactivity can be detected. The histological results with the mAbs are in agreement with previous biochemical results showing specific increases in the expression of $\mathrm{ON}_{1} / \mathrm{ON}_{2}$ and their mRNAs in retina during regeneration (Tesser et al., 1986).

The complexity of IF protein expression within the mammalian retina is well documented and reflects the retina's intricate morphology (Drager, 1983; Shaw and Weber, 1984). We have identified putative $60 \mathrm{~K}$ IF proteins in a retina cytoskeletal protein preparation that react with both the AIF $\mathrm{mAb}$ as well as anti-mammalian GFAP antisera (which also reacts with $\mathrm{ON}_{1}$ and $\mathrm{ON}_{2}$ ) (Jones and Schechter, 1987). Based on their electrophoretic mobility, these proteins are distinct from goldfish $\mathrm{ON}_{1}$ and $\mathrm{ON}_{2}$ and mammalian GFAP. Furthermore, polyclonal anti$\mathrm{ON}_{1} / \mathrm{ON}_{2}$ antisera does not recognize these $60 \mathrm{~K}$ proteins, whereas mAb 396 and mAb 187 do recognize these $60 \mathrm{~K}$ proteins in addition to $\mathrm{ON}_{1}$ and $\mathrm{ON}_{2}$ (Fig. 4).

\section{Neurofilament expression in growing neurites in culture}

Landreth and Agranoff (1976, 1979) described and characterized conditions in which goldfish retinal explants could be cultured. In this system, explants from retina, which are preconditioned by optic nerve crush, display vigorous and numerous neurite outgrowths in culture. One advantage of this system is that molecular events intrinsic and extrinsic to the retina can be conveniently investigated under controlled conditions (Heacock, 1982; Hopkins et al., 1985). In this report, we show the accumulation of neurofilament proteins into growing neurites from goldfish retinal explants. With respect to neurite labeling by $\mathrm{mAb} 396$, some neurites are first labeled after $6 \mathrm{~d}$ of culture; by $18 \mathrm{~d}$, all neurites contain $\mathrm{ON}_{1}$ and $\mathrm{ON}_{2}$. The decoration of 

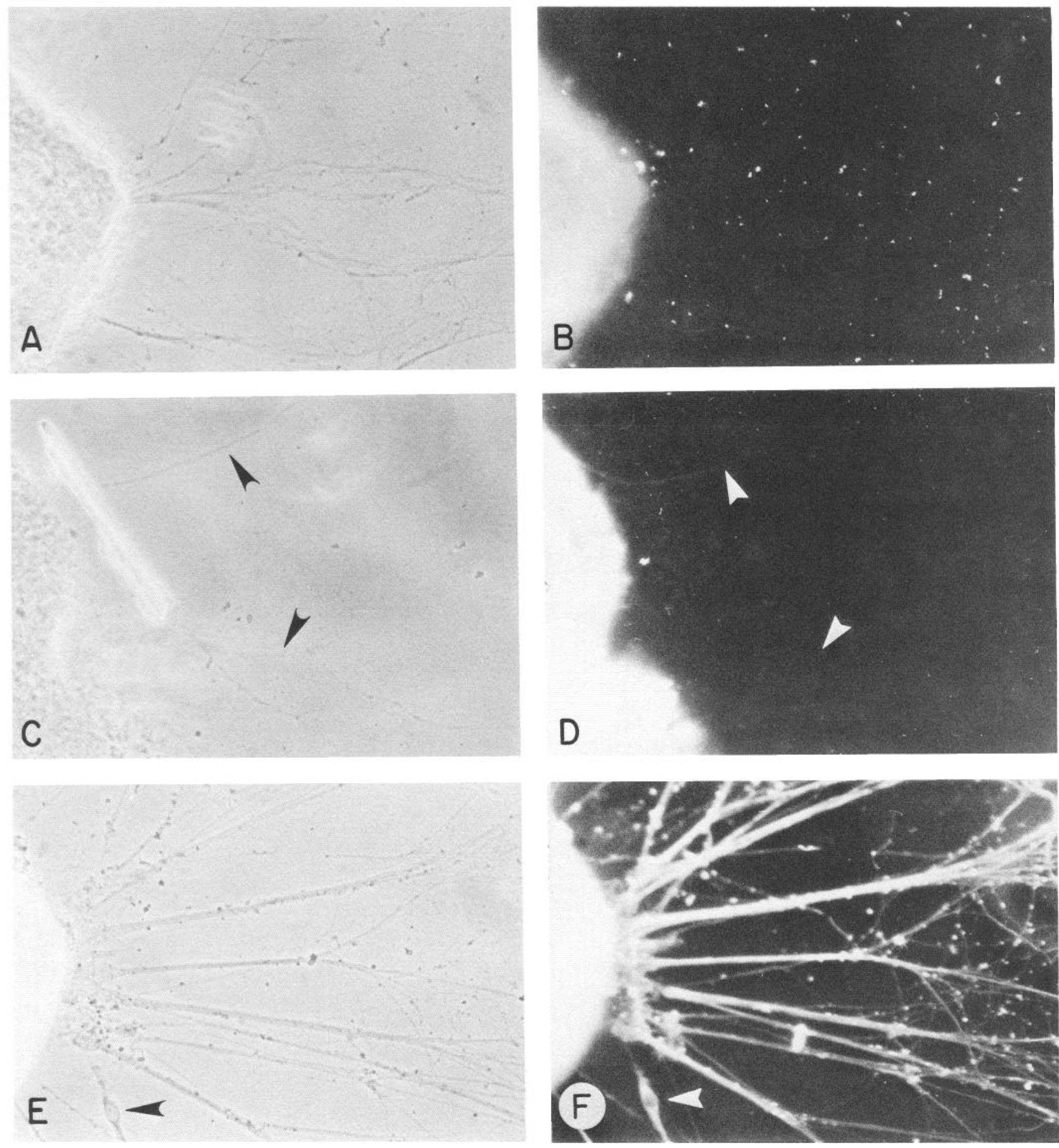

Figure 6. Expression of goldfish neurofilaments $\mathrm{ON}_{1}$ and $\mathrm{ON}_{2}$ in neurites of cultured retinal explants as detected by mAb 396 . Corresponding phase-contrast and fluorescence photomicrographs are shown. $A$ and $B$, Four days after culture. $C$ and $D$, Six days after culture. The neurite in the upper portion of these figures reacts weakly with $\mathrm{mAb} 396$, whereas another neurite in the lower portion of the figure does not exhibit reactivity (arrows). $E$ and $F$, Eighteen days after culture. See text for discussion of the cell labeled with an arrow. $\times 156$.

neurites with antibodies to proteins $\mathrm{ON}_{1}$ and $\mathrm{ON}_{2}$, taken together with our biochemical (Quitschke and Schechter, 1983b; Tesser et al., 1986) and histological (Fig. 4) results (which show that in vivo the proteins are expressed in retinal ganglion cells and transported into the optic nerve), demonstrate a specific intrinsic molecular marker that can be used to monitor neurite outgrowth. In addition, these results support previous observations (Johns et al., 1978) that the growing neurites emanate from retinal ganglion cells.

The time course of the appearance of antibody reactivity to proteins $\mathrm{ON}_{1}$ and $\mathrm{ON}_{2}$ in the neurites parallels our previous observations of the expression of these proteins in vivo. At the 
translational level in the retina, increased incorporation of ${ }^{35} \mathrm{~S}$-methionine into $\mathrm{ON}_{1}$ and $\mathrm{ON}_{2}$ is initially observed between 6 and $8 \mathrm{~d}$ after nerve crush, reaches a peak at $30 \mathrm{~d}$, and approaches precrush levels after $60 \mathrm{~d}$, corresponding to a return of vision, and a reestablished, ordered retinotopic projection (Quitschke and Schechter, 1983; Matsumoto et al., 1987). At the transcriptional level, increases in the levels of the mRNAs that program $\mathrm{ON}_{1}$ and $\mathrm{ON}_{2}$ synthesis also follow this time course (Tesser et al., 1986). Therefore, growing neurites in the retinal explant system act similarly to regenerating axons in vivo with respect to neurofilament expression.

These findings demonstrate the suitability of retinal explants in culture to serve as a model system with which to monitor axonal outgrowth. The neurofilaments $\mathrm{ON}_{1}$ and $\mathrm{ON}_{2}$ are appropriate markers for this process since their expression correlates well with the regrowth process under all the in vivo, in vitro, and ex vivo conditions examined thus far.

\section{References}

Attardi, D. G., and R. W. Sperry (1963) Preferential selection of central pathways by regenerating optic fibers. Exp. Neurol. 7: 46-64.

Benowitz, L. I., and E. R. Lewis (1983) Increased transport of 44,000to 49,000-dalton acidic proteins during regeneration of the goldfish optic nerve: A two-dimensional gel analysis. J. Neurosci. 3: 21532163.

Bignami, A. (1984) Glial fibrillary acidic (GFA) protein in Müller glia. Immunofluorescence study of the goldfish retina. Brain Res. 300:175178.

Bignami, A., T. Raju, and D. Dahl (1982) Localization of vimentin, the nonspecific intermediate filament protein in embryonal glia and in early differentiating neurons. Dev. Biol. 91: 286-295.

Chiu, F.-C., W. T. Norton, and K. L. Fields (1981) The cytoskeleton of primary astrocytes in culture contains actin, glial fibrillary acidic protein, and the fibroblast-type filament protein, vimentin. J. Neurochem. 37: 145-155.

Cochard, P., and D. Paulin (1984) Initial expression of neurofilaments and vimentin in the central and peripheral nervous system of the mouse embryo in utero. J. Neurosci. 4: 2080-2094.

Dahl, D., and A. Bignami (1973) Immunochemical and immunofluorescence studies of the glial fibrillary acid protein in vertebrates. Brain Res. 61: 279-293.

Dahl, D., C. J. Crosby, J. S. Sethi, and A. Bignami (1985) Glial fibrillary acidic (GFA) protein in vertebrates: Immunofluorescence and immunoblotting study with monoclonal and polyclonal antibodies. J. Comp. Neurol. 239: 75-88.

Drager, U. L. (1983) Coexsistence of neurofilaments and vimentin in a neurone of adult mouse retina. Nature 303: 169-172.

Franke, W. W. (1987) Nuclear lamins and cytoplasmic intermediate filament proteins: A growing multigene family. Cell 48: 3-4.

Geisler, N., U. Plessman, and K. Weber (1982) Related amino acid sequence in neurofilaments and non-neuronal intermediate filaments. Nature 296: 448-450.

Gcisler, N., E. Kaufmann, S. Fischer, U. Plessman, and K. Weber (1983) Neurofilament architecture combines structural principles of intermediate filaments with carboxy-terminal extensions increasing in size between triplet proteins. EMBO J. 2: 1295-1302.

Heacock, A. M. (1982) Glycoprotein requirement for neurite outgrowth in goldfish retina explants: Effects of tunicamycin. Brain Res. 241: $307-315$.

Heacock, A. M., and B. W. Agranoff (1976) Enhanced labeling of retinal protein during regeneration of the optic nerve in goldfish. Proc. Natl. Acad. Sci. USA 73: 828-832.

Hopkins, J. M., T. S. Ford-Holevinski, J. P. McCoy, and B. W. Agranoff (1985) Laminin and optic nerve regeneration in the goldfish. J. Neurosci. 5: 3030-3038.

Johns, P. R., and S. S. Easter (1977) Growth of the adult goldfish eye-increase in retinal cell number. J. Comp. Neurol. 176: 331-342.

Johns, P. R., A. M. Heacock, and B. W. Agranoff (1978) Neurites in explant cultures of adult goldfish retina derived from ganglion cells. Brain Res. 142: 531-537.

Jones, P. S., and N. Schechter (1987) Distribution of specific inter- mediate filament proteins in the goldfish retina, J. Comp. Neurol. 266: 112-121.

Jones, P. S., P. Tesser, K. T. Keyser, W. Quitschke, R. Samadi, H. J. Karten, and N. Schechter (1986a) Immunohistochemical localization of intermediate filament proteins of neuronal and nonneuronal origin in the goldfish optic nerve: Specific molecular markers for optic nerve structures. J. Neurochem. 47: 1226-1234.

Jones, P. S., J. M. Elias, and N. Schechter (1986b) An improved method for embedding retina for cryosectioning. J. Histotech. 9: 181182.

Landreth, G. E., and B. W. Agranoff (1976) Explant culture of adult goldfish retina: Effect of prior optic nerve crush. Brain Res. 118: 299303.

Landreth, G. E., and B. W. Agranoff (1979) Explant culture of adult goldfish retina: $\Lambda$ model for the study of CNS regeneration. Brain Res. 161: 39-53.

Langley, R. C., Jr., and C. M. Cohen (1987) Cell type-specific association between two types of spectrin and two types of intermediate filaments. Cell Motil. Cytoskeleton 8: 165-173.

Larrivee, D. L., and B. Grafstein (1987) Phosphorylation of proteins in normal and regenerating goldfish optic nerve. J. Neurochem. 49: 1747-1757.

Lowry, O. H., N. J. Rosebrough, A. L. Far, and R. H. Randall (1951) Protein measurement with the Folin phenol reagent. J. Biol. Chem. 193: 265-275.

Matsumoto, N., M. Kometani, and K. Nagano (1987) Regenerating retinal fibers of the goldfish make temporary and unspecific but functional synapses before forming the final retinotopic projection. Neuroscience 22: 1103-1110.

Meyer, R. L. (1978) Evidence from thymidine labeling for continuing growth of retina and tectum in juvenile goldfish. Exp. Neurol. 59: 99-111.

O'Farrell, P. H. (1975) High resolution two-dimensional electrophoresis of proteins. J. Biol. Chem. 250: 4007-4021.

Perry, G. W., D. W. Burmeister, and B. Grafstein (1985) Changes in protein content of goldfish optic nerve during degeneration and regeneration following nerve crush. J. Neurochem. 44: 1142-1151.

Perry, G. W., D. W. Burmeister, and B. Grafstein (1987) Fast axonally transported proteins in regenerating goldfish optic axons. J. Neurosci. 7: 792-806.

Pruss, R. M., R. Mirsky, M. C. Raff, R. Thorpe, A. S. Dowding, and B. H. Anderton (1981) All classes of intermediate filaments share a common antigenic determinant defined by a monoclonal antibody. Cell 27: 419-428.

Quitschke, W., and N. Schechter (1983a) Specific optic nerve proteins during regeneration of the goldfish retinotectal pathway. Brain Res. 258: 69-78.

Quitschke, W., and N. Schechter (1983b) In vitro protein synthesis in the goldfish retinotectal pathway during regeneration: Evidence for specific axonal proteins of retinal origin in the optic nerve. J. Neurochem. 41: 1137-1142.

Quitschke, W., and N. Schechter (1984) 58,000 dalton intermediate filament proteins of neuronal and nonneuronal origin in the goldfish visual pathway. I. Neurochem. 42: 569-576.

Quitschke, W., and N. Schechter (1986) Homology and diversity between intermediate filament proteins of neuronal and nonneuronal origin in goldfish optic nerve. J. Neurochem. 46: 545-555.

Quitschke, W., A. Francis, and N. Schechter (1980) Electrophoretic analysis of specific proteins in the regenerating goldfish retinotectal pathway. Brain Res. 201: 347-360.

Quitschke, W., P. S. Jones, and N. Schechter (1985) A survey of intermediate filament proteins in optic nerve and spinal cord: Evidence for differential expression. J. Neurochem. 44: 1465-1476.

Schechter, N., A. Francis, D. G. Deutsch, and M. S. Gazzaniga (1979) Recovery of tectal nicotinic-cholinergic receptor sites during optic nerve regeneration in goldfish. Brain Res. 166: 57-64.

Shaw, G., and K. Weber (1984) The intermediate filament complement of the retina: A comparison between different mammalian species. Eur. J. Cell Biol. 33: 95-104.

Sperry, R. (1963) Chemoaffinity in the orderly growth of nerve fiber patterns and connections. Proc. Natl. Acad. Sci. USA 50: 703-710.

Steinert, P. M., and D. A. D. Parry (1985) Intermediate filaments: Conformity and diversity of expression and structure. Annu. Rev. Cell Biol. 1: 41-65.

Tapscott, S. S., G. S. Bennett, Y. Toyama, F. Kleinbart, and H. Holtzer 
(1981) Intermediate filament proteins in the developing chick spinal cord. Dev. Biol. 86: 40-54.

Tesser, P., P. S. Jones, and N. Schechter (1986) Elevated levels of retinal neurofilament $\mathrm{mRNA}$ accompany optic nerve regeneration. J. Neurochem. 47: 1235-1243.

Towbin, H., T. Staehelin, and J. Gordon (1979) Electrophoretic trans- fer of proteins from polyacrylamide gels to nitrocellulose sheets: Procedure and some application. Proc. Natl. Acad. Sci USA 76: 43504354.

Walter, M. F., and H. Biessmann (1984) A monoclonal antibody that detects vimentin-related proteins in invertebrates. Mol. Cell Biochem. 60: $99-108$ 